\title{
Implement of Predrying to Enhance Productivity of Existing Stenter in Knit Finishing Industry
}

\author{
Shaikh Md Mominul Alam ${ }^{1 *}$ and Shariful Islam² \\ ${ }^{1}$ Department of Textile Machinery Design and Maintenance,Faculty of Science and Engineering, Bangladesh University of \\ Textiles, Tejgaon, Dhaka 1208, Bangladesh \\ ${ }^{2}$ Department of Fabric Engineering,Bangladesh University of Textiles.Tegjaon, Dhaka, 1208, Bangladesh \\ *Corresponding author: Shaikh Md Monimul Alam, Department of Textile Machinery Design and Maintenance,Faculty of Science \\ and Engineering, Bangladesh University of Textiles, Tejgaon, Dhaka 1208, Bangladesh
}

\section{ARTICLE INFO}

Received: 䋃 August 18, 2020

Published: August 28, 2020

Citation: Shaikh Md Mominul Alam, Shariful Islam. Implement of Predrying to Enhance Productivity of Existing Stenter in Knit Finishing Industry. Biomed J Sci \& Tech Res 29(5)-2020. BJSTR. MS.ID.004863.

\begin{abstract}
The aim of this paper is to enhance the productivity of existing stenter machine in knitting manufacturing industry. Stenter is one of the most costly machine in knit finishing industry. When the production per hour in kilogram of this machine was increased, then the production cost per kilogram of the fabric was decreased. To decrease the production cost, enhancing the productivity of stenter is an important issue in textile industry. The productivity of the existing stenter was increased by minimum $25 \%$ after implementing an additional predrying unit of the existing stenter at reasonable price which is described in this paper. Most of the characteristics of the fabric were same as before.
\end{abstract}

Keywords: Stenter; Predrying; Vaporization; Shrink; Enhance; Productivity

\section{Introduction}

This research is significant in the field of knitting technology. Stenter is a machine or apparatus use for stretching or stentering fabrics. For decades, the stenter frame has been a global synonym of top-rate technology for best results in the finishing treatment of woven and knitted fabrics [1]. Cotton fabric shrinks widthwise and weft distorted due to pretreatment and dyeing process [2]. The main function of the stenter is to stretch the fabric width wise and to recover the uniform width [3]. The purpose of the stenter machine is to bring the length and width to pre-determined dimensions and also for heat setting and it is used for applying finishing chemicals and also shade variation is adjusted. Stenter is used for open form fabric [4].

New features make the stenter frame now even more economical in operation, more universal in use and improve its eco balance even further [5]. Additionally, there are special solutions for pigment dyeing processes and the even more profitable finishing of knitted fabrics [6]. Heat setting is done by the stenter for lycra fabric, synthetic and blended fabric [7].
In Stenter, squeezed wet fabric pass through the first chamber of stenter at the highest of about 150-2000C and water inside fabric is vaporized [8]. If speed of the fabric is increased then, the rate of the vaporization decreased and vice-versa [9]. Though the speed capacity of a stenter is higher but it cannot be used $100 \%$ but 50 $75 \%$ at the best due to vaporization of water mainly. At the end, total production of a stenter decrease [10]. In this situation, a predrying unit with steam temperature can evaporate water and feed dry fabric in first chamber which can increase speed of inlet fabric as well as productivity of the stenter [11]. The present research work is on the basis of this principle.

\section{Materials and Method}

\section{Technical Specifications of Predrier}

a) Number of Steam Cylinder: 4 pieces

b) Working width: $1800 \mathrm{~mm}-3400 \mathrm{~mm}$

c) Made of: AlSI 304 Stainless Steel

d) Steam Cylinder Diameter: $640 \mathrm{~mm}$ 
e) Idler Cylinder: 6 pieces (0 114mm AlSI 304 Stainless Steel)

f) Opener Cylinder: 1 Piece (0 114mm AlSI 302 Stainless Steel)

g) Separate Steam Head for each Cylinder.

h) Installed Power: 5.75KW

i) Steam Consumption per Cylinder: $120 \mathrm{Kg} / \mathrm{h}$ (Calculation is valid for first heating)

\section{The Experimentation}

The Loadcell of Cylinder and control system, it keeps the tension of the fabric constant even in the most sensitive fabrics. The cylinder surface is coated with Teflon. The ability to keep the cylinder temperature constant in the heating system. Figures $1 \& 2$ shows the Predrier Cylinders. Figure 3 shows the Predrier Cylinders on the top of existing stenter machine in industry.

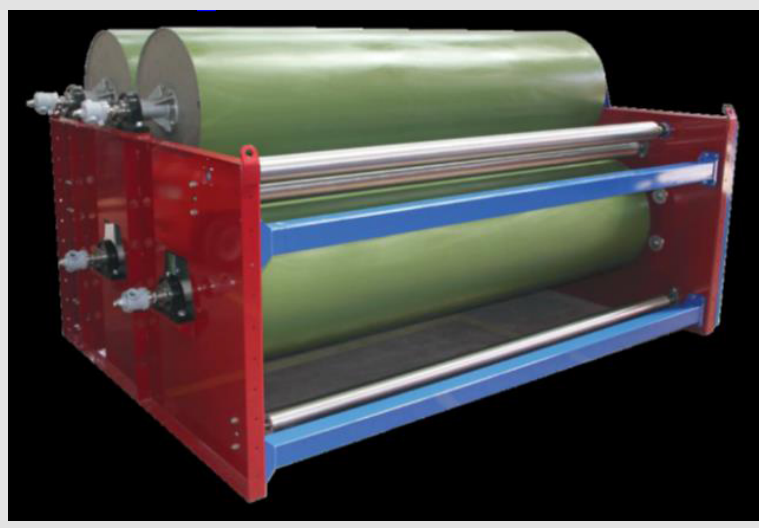

Figure 1: Predrier Cylinders.

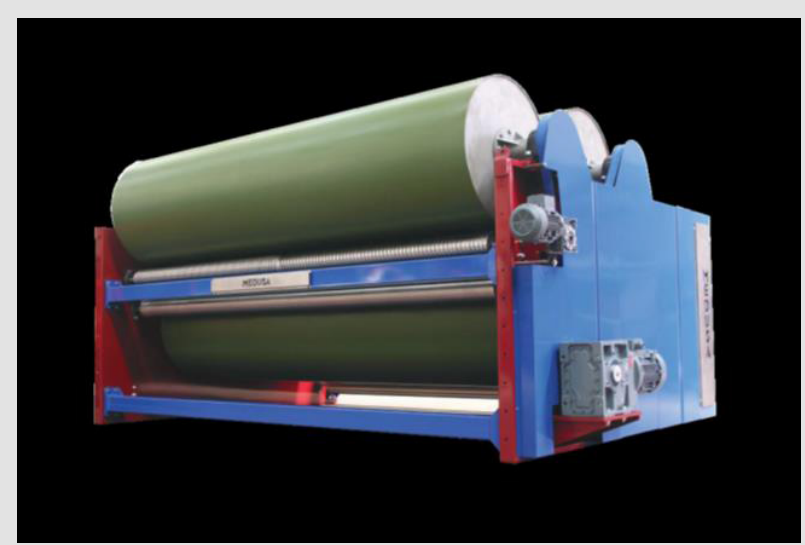

Figure 2: Predrier Cylinders.

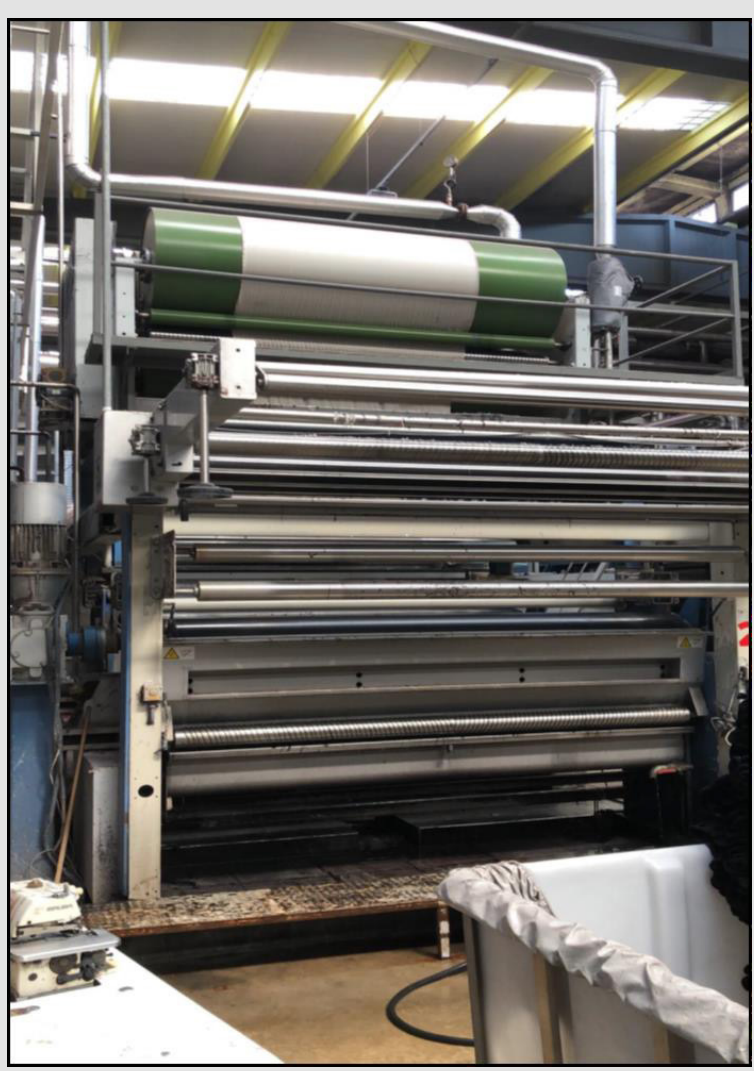

Figure 3: Predrier Cylinders on the top of existing stenter machine in industry.

\section{Machine Location}

The drying unit do not occupied space on floor but is placed on the top about 1.5 meter of the existing washing or penetrating bath of the stenter by the help of cast iron pillar. Additional steam, electricity and air connection are connected to run the drying unit smoothly.

\section{Results and Discussion}

Fabric pass through inlet, weft straightener if present, washing baths and then predrying unit and stenter. The speed of predrier is synchronized with existing stenter through electrical arrangements. The unit weight (GSM) of the inlet fabric at dry condition is about 90 $95 \%$ in compare to predried fabric which conclude that the fabric almost dried after using predrier. The speed of the fabric in stenter can increase minimum $30 \%$ additionally after using predrier. With pre-drying process, fabric passes through heated cylinders so that the evaporation starts before the main process. Pre-Dryer machine reduces humidity. With this way, machine capacity and production speed increases. System is designed to ensure that only the back side of the fabric touches the surface of the cylinders. The front side 
of the fabric does not touch the hot surface, so there is no glace or chromatic aberration on the fabric surface. The cylinder surface is coated with Teflon to prevent adhesion of fluff and silicone residues. All surfaces are made of stainless steel to withstand corrosion of steam and moisture.

\section{Conclusion}

It is seen from the research that the implementation of predrier in stenter has remarkable technical, financial improvements for textile industries. Industries or machine manufacturers should redesign stenter including predrying unit to enhance productivity of stenter. There are hundreds of knit composite mills in Bangladesh and around the world where stenters are used. The introduction of predrier in stenter increase the production of existing machine about minimum $25 \%$ successfully. It takes back the investment price within maximum 6 months whereas life time of the unit is at least ten years.

\section{Acknowledgements}

This predrying system was supplied by Fair International Ltd. This development was carried out in: S M Knitwears Ltd. Shirirchala, Bhabanipur, Gazipur, Bangladesh. We would like to thank the managements of SM Knitwears Ltd. for their cooperation to purchase and implement the predrying system for their existing stenter.

\section{References}

1. Akan AE, Ünal, F (2020) Thin-Layer Drying Modeling in the Hot OilHeated Stenter. International Journal of Thermophysics 41(8): 1-27.

\section{ISSN: 2574-1241}

DOI: $10.26717 /$ BJSTR.2020.29.004863

Shaikh Md Mominul Alam. Biomed J Sci \& Tech Res

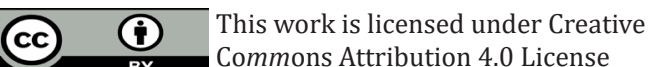

Submission Link: https://biomedres.us/submit-manuscript.php
2. Wilmer Parra Llanos J, Mailde Santos R, Bastos Quadri M, Oliveira Martins I (2020) Phenomenological modeling and simulation of a textile stenter. Textile Research Journal.

3. Şekkeli M, Keçecioğlu ÖF (2012) Scada Based An Energy Saving Approach To Operation Of Stenter Machine In A Textile Plant Using Waste Heat Recovery System. Journal Of Textile \& Apparel/Tekstil Ve Konfeksiyon 22(3).

4. Laurie KS (1960) Stenter drying and heat treatment of fabric. Journal of the Textile Institute Proceedings 51(9): 562-565.

5. Cay A, Tarakçıŏlu I, Hepbasli A (2010) Exergetic analysis of textile convective drying with stenters by subsystem models: Part 2-Parametric study on exergy analysis. Drying Technology 28(12): 1368-1376.

6. ISLAM S, ALAM SMM (2018) Investigation of the acoustic properties of needle punched nonwoven produced of blend with sustainable fibers. International Journal of Clothing Science and Technology 30(3): 444458.

7. Tester D, Slevin P (1993) The Role of Stenter Settings in Determining the Dimensional and Mechanical Properties of Wool Fabric. Journal of the Textile Institute 84(4): 659-668.

8. Islam S, Alam SMM, Akter S (2018) Identifying a suitable heat setting temperature to optimize the elastic performances of cotton spandex woven fabric. Research Journal of Textile and Apparel 22(3).

9. Islam S, Alam SMM Akter S (2020) Influence of thermal conduction on the stretching behaviour of core spandex cellulosic fabrics. Materials today proceedings.

10. Özer B, Güven B (2020) Energy efficiency analyses in a Turkish fabric dyeing factory. Energy Sources, Part A: Recovery, Utilization, and Environmental Effects pp. 1-23.

11. Catalogues of Medusa Kimya Proje Makine Teknolojileri ve Muhendislik Hizmetleri San.Tic.Ltd.Şti., Turkey.

$\begin{array}{ll}\text { BIOMEDICAL } & \text { Assets of Publishing with us } \\ \text { RESEARCHES } & \text { - Global archiving of articles } \\ & \text { - Immediate, unrestricted online access } \\ & \text { - Rigorous Peer Review Process } \\ & \text { - Authors Retain Copyrights }\end{array}$

